\title{
Correlation Between Consumption of Protein and Vitamin C Among Children Aged 12-24 Months with Anemia in the South Sumedang District
}

\section{Fardila Elba ${ }^{1}$, Eneng Daryanti ${ }^{2}$, Lani Gumilang ${ }^{1}$, Triastika Ayu Nurjannah¹, and Nurlaela Effendy ${ }^{1}$}

${ }^{1}$ Diploma IV Of Midwifery Program Study Universitas Padjadjaran

${ }^{2}$ Diploma III Of Midwifery Program Study, Bhakti Kencana University (UBK)

ORCID:

Fardila Elba: https://orcid.org/0000-0001-7998-509X

\section{Abstract}

Anemia commonly occurs in infants aged 12-24 months. One of the causes of anemia in infants is a lack of vitamin $C$ and protein. This study aimed to determine the correlation between protein intake and vitamin $C$ on the incidence of anemia in children under

Corresponding Author:

Fardila Elba

fardilaelba@yahoo.com

Published: 15 March 2021

Publishing services provided by Knowledge E

(c) Fardila Elba et al. This article is distributed under the terms of the Creative Commons

Attribution License, which permits unrestricted use and redistribution provided that the original author and source are credited.

Selection and Peer-review under the responsibility of the IVCN Conference Committee. 12-24 months. This research uses an analytic study design with a cross-sectional design. Randomization was conducted to obtain a study sample consisting of 96 toddlers aged 12-24 months. The instrument uses FFQ (Food Frequency Questionnaire) with bivariate (chi-square) and multivariate (multiple logistic regression) analysis. The univariate study results showed that out of 96 toddlers, 42 had anemia 42 (43.8\%) and 54 did not (56.3\%). Based on the bivariate test results, it was found that protein intake of the fulfilled hemoglobin levels had anemia $14.8 \%$ and those that were fulfilled did not experience anemia $85.2 \%$ with the result $p=0.000$. Based on the fulfilled vitamin $C$ intake, $18.9 \%$ anemia was fulfilled but $81.1 \%$ did not experience anemia with the result $p$ $=0.001$. Based on the multivariate test, protein intake was not fulfilled and had anemia $p=0.001, O R=15.01$. This study concludes that there is a relationship between protein and vitamin $\mathrm{C}$ intake on the incidence of anemia in infants, and protein intake that is not met will experience a $15 x$ more significant influence on the incidence of anemia in infants

Keywords: Children under five, Anemia, Protein intake, Vitamin C intake

\section{Introduction}

One of Indonesia's health problems is anemia, which still occurs in children aged 12-24 months [1]. Anemia is an important health problem because this disease is a cause of chronic disability which has a major impact on health, economic, and social welfare conditions [2]. Anemia is a condition in which hemoglobin $(\mathrm{Hb})$ levels are lower than normal values [3]. Based on the 2018 RISKESDAS, it is known that the incidence of 
anemia in children under five up to $38.5 \%$ [4]. One of the causes of anemia in toddlers is the lack of nutrients that play a role in forming hemoglobin and lack of nutritional intake or absorption disorders in the body. Protein intake plays an important role in the transportation of iron in the body. Therefore, the lack of protein intake can cause iron transport to be inhibited, which results in iron deficiency resulting in anemia. Other micronutrients include vitamin $C$ intake which plays a role in influencing iron absorption in the body. If a deficiency can be bad for toddlers [5]. Based on Indonesian Health Information in 2018 , the percentage of children under five who experience a deficiency in protein intake is $31.90 \%$, but it is not known how much is the percentage of deficiency in vitamin $\mathrm{C}$ intake in children under five in Indonesia [6]. Other factors can also influence it, namely based on the parents' characteristics such as occupation and parental education. Also, other factors can affect the incidence of anemia in children under five, namely work and parental education. It is known that maternal education is related to knowledge, so that understanding in providing good food intake to children, than mothers who do not work tend to approach adequacy in providing food to children compared to working mothers so that it will have an impact on the incidence of anemia in children under five.[7].

\section{Methods}

This research is a quantitative study with a cross-sectional design. Conducted the Sumedang Selatan Puskesmas, Sumedang Regency in August - November 2019. The sample was selected through a probability sampling technique with a proportioned simple random sampling method consisting of 96 toddlers aged 12-24 months. The research protocol was approved by the Health Research Ethics Committee, Faculty of Medicine, Padjadjaran University. The purpose of this study was to determine the relationship between protein and vitamin $C$ intake on the incidence of anemia in children aged 12-24 months and to see how much influence these two intakes had on the incidence of anemia. The data used in this study are primary. Primary data were obtained through checking hemoglobin levels using a digital HB device and a food record questionnaire within three days. The inclusion criteria in this study were toddlers aged 12-24 months, toddlers who were approved by the mother to be respondents, and toddlers whose address was in the Sumedang Selatan Public Health Center, Sumedang Regency, while the exclusion criteria in this study were toddlers who were/suffering from illness and mothers who do not agree to be a respondent. The process of collecting data in this study was the identity of the respondents, the results of the examination of 
$\mathrm{Hb}$ levels, and the intake of protein and vitamin c. After the researcher collected the respondents according to the inclusion criteria, the researcher checked the toddler's $\mathrm{Hb}$ level then gave the respondent a food record form to be filled in within 3 days by explaining how to fill it, after the data was collected the researcher processed it using Nutrisurvey software so that the protein and vitamin $C$ intake values were obtained. consumed by toddlers.

In this study, data analysis involved: [8]

1. Univariate analysis to find the incidence of anemia in respondents.

2. Bivariate analysis to find the relationship between protein and vitamin $\mathrm{C}$ intake and the incidence of anemia. Before analysis, the normality test using the KolmogorovSmirnov test was carried out because the sample was more than 50 . It was found that the data were normally distributed $(\mathrm{p}>0.05)$. Therefore, bivariate analysis was performed using independent t-test

3. Multivariate analysis to find out how much influence the two intakes have on the incidence of anemia

\section{Results}

\subsection{Research result}

\subsubsection{Characteristics of Toddler's Parents}

Table 1 shows respondents at the Sumedang Selatan Community Health Center stated that most mothers' jobs were housewives, as many as 78.1\%. In terms of educational background, the highest mother's education is senior high school as much as $45.8 \%$ and the lowest mother's education is primary school as much as $13.5 \%$.

\subsubsection{Bivariate Analysis}

Based on Table 2 shows, it is found that the fulfilled protein intake of hemoglobin levels has anemia of 8 children under five (14.8\%) and 46 children under five (85.2\%) are not experiencing anemia. The unfulfilled protein intake experienced anemia of 34 children under five (81.0\%), and eight children under five (19.0\%) did not have anemia with the result $p=0.000$. Based on the fulfilled vitamin $C$ intake, ten under-fives (18.9\%) had anemia, and 43 under-fives (81.1\%) had no anemia. Unfulfilled vitamin c intake 
TABLE 1: Characteristics of Toddler's Parents

\begin{tabular}{l|c|c|}
\hline Characteristics & F & $\%$ \\
\hline Education & 13 & 13,5 \\
\hline Primary school & 25 & 26,0 \\
\hline Junior high school & 44 & 45,8 \\
\hline Senior High School & 14 & 14,6 \\
\hline College & & \\
\hline Profession & 75 & 78,1 \\
\hline Housewife & 2 & 2,1 \\
\hline Labor & 13 & 13,5 \\
\hline Entrepreneur & 1 & 1,0 \\
\hline Civil servants & 2 & 2,1 \\
\hline Teacher & 1 & 1,0 \\
\hline Lecturer & 1 & 1,0 \\
\hline Midwife & 1 & 1,0 \\
\hline Doctor & & \\
\hline
\end{tabular}

TABLE 2: The Relationship of Protein and Vitamin C Intake of Anemia

\begin{tabular}{|c|c|c|c|c|c|c|c|}
\hline \multicolumn{7}{|c|}{ Anemia } & p-value \\
\hline & \multicolumn{2}{|c|}{ Anemia } & \multicolumn{2}{|c|}{ No Anemia } & \multicolumn{2}{|c|}{ Total } & \\
\hline & \multicolumn{2}{|c|}{$\%$} & \multicolumn{2}{|c|}{$\%$} & \multicolumn{2}{|c|}{$\%$} & \\
\hline \multicolumn{8}{|l|}{ Protein } \\
\hline Fulfilled & 8 & 14,8 & 46 & 85,2 & 54 & 100 & \\
\hline Not fulfilled & 34 & 81,0 & 8 & 19,0 & 42 & 100 & 0,000 \\
\hline \multicolumn{8}{|l|}{ Vitamin C } \\
\hline Fulfilled & 10 & 18,9 & 43 & 81,1 & 53 & 100 & \\
\hline Not fulfilled & 32 & 74,4 & 11 & 25,6 & 43 & 100 & 0,001 \\
\hline Total & 42 & 43,75 & 54 & 56,25 & 96 & 100 & \\
\hline
\end{tabular}

${ }^{*}$ Chi-square

experienced anemia in 32 children under five (74.4\%), and 11 children under five (25.6\%) did not experience anemia with $\mathrm{p}=0.001$.

\subsubsection{Multivariate Analysis}

TABLE 3: Results of the Analysis of How to Influence the Relationship between Protein and Vitamin C Intake on the Incidence of Anemia
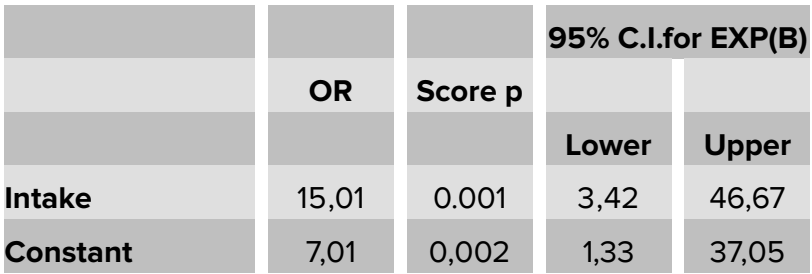
Table 3 shows that multivariate analysis is used to see between the most influential independent variables and the dependent variable. The research used is logistic regression because this study using a categorical scale. Based on the data in table 3 , the results show that unfulfilled protein intake and anemia $p=0.001$, OR $=15.01$ Unfulfilled protein intake will have a $15 x$ more significant effect on the incidence of anemia in toddlers

\section{Discussion}

\subsection{Relationship between protein intake and anemia}

The relationship between protein intake and the incidence of anemia in toddlers aged 12-24 months has a value of $p=0.000<0.05$, which means that there is a relationship. Protein has the strongest relationship with hemoglobin levels. Especially foods of animal origin contain lots of iron. Transferrin is a glycoprotein that is synthesized in the liver. Protein plays a central role in the body's iron metabolism because transferrin transports iron in the circulation to places where iron is needed, such as from the intestine to the bone marrow to form new hemoglobin. Ferritin is another protein that is important in iron metabolism. Under normal conditions, ferritin stores iron, which can be recovered for use as needed [9].

This study is in line with the research of Imtiyas, et al. (2017), which states that there is a relationship between protein intake and the incidence of anemia in children, which has a significant result, namely $p<0.05(p=0.028)[10]$. The research by Sharon et al. (2015) states that there is a statistically significant relationship $(p=0.005)$ between protein intake and the incidence of anemia, based on the results of the study showing that lack of protein intake can increase the likelihood of developing anemia [11]. And research by Siti et al. (2016) states that there is a relationship between protein intake and the incidence of anemia with a value of $p=0.000<0.005$ [12].

Protein is a significant source of iron and folic acid. So that if you are deficient in protein, it will reduce your intake of iron and folic acid. Protein plays a role in forming blood grains or hemopoiesis. Besides that, protein also has an important role in the transportation of iron in the body. If the protein intake pattern is lacking, it will cause iron transport to be hampered, which results in iron deficiency [13]. 


\subsection{The Relationship of Vitamin C Intake Against The Incidence of Anemia}

The relationship between protein intake and the incidence of anemia in children aged 12-24 months has a value of $p=0.001<0.05$, which means there is a relationship. Vitamin $C$ is an essential element needed by the body for the formation of red blood cells. Vitamin $C$ inhibits the formation of hemosiderin, which is difficult to mobilize to liberate iron when needed. The presence of vitamin $C$ in the food consumed will provide an acidic atmosphere, thereby facilitating ferric iron reduction to ferrous, which is more easily absorbed by the small intestine. The absorption of iron in the non-heme form is increased fourfold when there is vitamin $C$ [14].

This study is in line with research that states that vitamin $c$ intake has a significant relationship with anemia in children $(p=0.002)$ [15]. Based on research by Endar et al. (2015), there is a relationship between vitamin $C$ intake and the incidence of anemia with a value of $p=0.000<0.05$ [16]. And based on research by Allenfina et al. (2015) said that there was a significant relationship $p=0.042$ between vitamin $c$ intake and anemia [17]. It is known that vitamin $C$ can help iron absorption in preventing anemia, but if the iron is consumed in limited quantities, the function of vitamin $C$ as an iron enhancer will not work [18].

Apart from intake, other factors can influence anemia, based on the parents' characteristics, such as occupation and parental education. Based on research by Septiana (2015), there is a relationship between maternal education and the incidence of anemia in children under five with a significant value of $p=0.014<0.05$, and there is a relationship between maternal employment status and anemia prevention in children under five with $p=0.003<0.05$. It is known that the higher the mother's education, the better the knowledge in preventing anemia because the higher a person's education level, the easier it is to receive information so that the more knowledge one has. Mothers with a high level of education and have better abilities are easier to understand every information they get. The level of knowledge of mother nutrition as a household manager will affect the types of food consumed in the household daily. And work as a housewife allows for greater allocation of time for mothers to pay attention to consumption and health for themselves and their families. Mother's status and type of work affect the availability of time for mothers to manage food. This tends to be a determinant of the diversity of household food consumption [19]. 


\section{Conclusion}

This study concludes that most of the respondents' protein intake and vitamin C intake have not been fulfilled. There is a relationship between protein and vitamin $C$ intake on the incidence of anemia in toddlers, and unfulfilled protein intake will experience 15 times greater effect on the incidence of anemia in toddlers

\section{References}

[1] Singh, P. (2014). Extent of Anaemia among Preschool Children in EAG States, India: A Challenge to Policy Makers. Hindawi Publishing Corporation.

[2] Suryani, D., Hafiani, R. and Junita, R. (2015). Analisis pola makan dan anemia gizi besi pada remaja putri Kota Bengkulu. Jurnal Kesehatan Masyarakat Andalas, vol. 10, issue 1, pp. 11- 18.

[3] Masthalina, H. (2015). Pola Konsumsi (faktor inhibitor dan enhancer fe) terhadap Status Anemia Remaja Putri. Jurnal Kesehatan Masyarakat, vol. 11, issue 1, pp. 80-6.

[4] Riset Kesehatan Dasar (Riskesdas) Badan Penelitian dan Pengembangan Kesehatan Kementerian RI 2018.

[5] VanBuskirk, K. (2014). Pediatric Anemia in Rural Ghana: A Cross-Sectional Study of Prevalence and Risk Factors. Journal of Tropical Pediatrics, vol. 60, issue 4.

[6] Profil Kesehatan Indonesia Jakarta: Kementerian Kesehatan Republik Indonesia 2018.

[7] Nofiani, A. (2015). Faktor-Faktor yang Berhubungan dengan Anemia pada Balita Usia 12-59 Bulan di Indonesia (Analisis data Riskesdas 2013).

[8] Dahlan, M. S. (2014). Statistik untuk Kedokteran dan Kesehatan: Deskriptif, bivariate, dan multivariate dilengkapi dengan aplikasi SPSS. Jakarta: Epidemiologi Indonesia.

[9] Rahmad, A. H. A. (2017). Pengaruh Asupan Protein dan Zat Besi (Fe) terhadap Kadar Hemoglobin pada Wanita Bekerja. Jurnal Kesehatan, vol. 8, issue 3, pp. 321-5.

[10] Safitri, I. R. and Dasuki, M. S. (2020). Hubungan Asupan Protein, Pola Asuh Gizi, Dan Pengetahuan Ibu Tentang Gizi Dengan Kejadian Anemia Pada Anak Tk Di Kartasura.

[11] Soedijanto, S. G. (2015). Hubungan Antara Asupan Zat Besi dan Protein dengan Kejadian Anemia pada Siswi SMP Negeri 10 Manado. Pharmacon, vol. 4, issue 4.

[12] Paputungan, S. R. (2016). Hubungan Antara Asupan Zat Besi Dan Protein Dengan Kejadian Anemia Pada Siswi Kelas VIII Dan IX Di SMP N 8 Manado. Pharmacon, vol. 5 , issue 1. 
[13] Pratiwi, L. Y., Puspitasari, D. I. and Gz, S. (2017). Hubungan Asupan Protein Dan Status Gizi Dengan Kadar Hemoglobin Ibu Hamil Di Desa Demakan Kecamatan Mojolaban. Kabupaten Sukoharjo: Universitas Muhammadiyah Surakarta.

[14] Adriani, D. M. and Bambang, P. D. (2012). Pengantar Gizi Masyarakat. Jakarta: Kencana.

[15] Paramitha, S. (2015). Hubungan Asupan Zat Besi (Fe), Vitamin C dan Kejadian Anemia Pada Anak Sekolah Dasar Kelas 5 SDN Mandiri 3 Kota Cimahi Tahun 2015. (Karya Tulis IImiah Program Studi Diploma III, Jurusan Gizi Politeknik, Kesehatan Kemenkes Bandung, 2015).

[16] Choiriyah, E. W. (2015). Hubungan Tingkat Asupan Protein, Zat Besi dan Vitamin C dengan Kejadian Anemia pada Remaja Putri Kelas X dan XI SMA Negeri 1 Polokarto. Kabupaten Sukoharjo: Universitas Muhammadiyah Surakarta.

[17] Tadete, A., Maladona, N. and Basuki, A. (2013). Hubungan Antara Asupan Zat Besi, Protein dan Vitamin C Dengan Kejadian Anemia pada Anak Sekolah Dasar di Kelurahan Bunaken Kecamatan Bunaken Kepulauan Kota Manado. Indonesian Journal of Public Health, vol. 3, issue 1.

[18] Setijowati, N. (2014). Hubungan Antara Asupan Zat Gizi Mikro Seng (Zinc) Dengan Dismenorea Primer Pada Remaja Putri Di Man Kota Blitar. Malang: Universitas Brawijaya.

[19] Rahmawati, S. (2015). Hubungan Tingkat Pendidikan dan Status Pekerjaan Ibu dengan Pengetahuan Ibu tentang Anemia pada Anak Balita di Kelurahan Nambangan Kidul Kecamatan Manguharjo Kota Madiun. Universitas Muhammadiyah Surakarta. 